\title{
NEW DRUGS FOR THE TREATMENT OF DYSLIPIDEMIA
}

\author{
Aleksandra Novaković ${ }^{1}$, Marija Marinko ${ }^{1}$, Ivan Stojanović ${ }^{2,3}$, \\ Dragoslav Nenezić2,3, Predrag Milojević ${ }^{2,3}$, Vladimir Kanjuh ${ }^{4}$
}

\begin{abstract}
Dyslipidemia is the leading risk factor for the development of atherosclerosis and associated consequences, such as coronary heart disease, ischemic cerebrovascular and peripheral vascular disease. These diseases are the major cause of mortality in the world and in Europe as well, where they are responsible for around $45 \%$ of all deaths. Treatment of dyslipidemia includes the use of statins, ezetimibe, fibrates, niacin, bile acids sequestrants and omega-3 fatty acids. Although statins play the major role in dyslipidemia treatment by reducing the risk of cardiovascular (CV) events by $30 \%$, there is a need for additional new drugs that reduce the residual risk even more. PCSK9 inhibitors, apolipoprotein B (apoB) synthesis inhibitors, MTP inhibitors and CETP inhibitors are already approved for the specific indications, or are in the advanced stages of clinical investigation. Two PCSK9 inhibitors, alirocumab and evolocumab are approved for use in combination with statins for the treatment of heterozygous familial hypercholesterolemia (FH), but also in patients with clinical atherosclerotic CV diseases who require additional low-density lipoprotein cholesterol (LDL-C) level reduction. In addition, evolocumab is approved for use in patients with homozygous FH. Mipomersen, apoB synthesis inhibitor, lomitapide, and oral MTP inhibitor are currently approved in the treatment of patients with homozygous $\mathrm{FH}$ as an adjunct to the maximum tolerated doses of statins and other lipidlowering drugs. Although the new lipid-lowering agents produce significant LDL-C level reduction, more clinical studies are necessary to confirm their efficacy and safety in dyslipidemia treatment.
\end{abstract}

Acta Medica Medianae 2018;57(1):54-63.

Key words: dyslipidemia, PCSK9 inhibitors, mipomersen, lomitapide, CETP inhibitors

\footnotetext{
${ }^{1}$ University of Belgrade, Faculty of Pharmacy, Department of Pharmacology, Belgrade, Serbia

${ }^{2}$ University of Belgrade, Faculty of Medicine, Belgrade, Serbia

${ }^{3}$ Institute for Cardiovascular Diseases "Dedinje", Belgrade,

Serbia

${ }^{4}$ Academy of Sciences and Arts, Belgrade, Serbia
}

Contact: Aleksandra Novaković

Department of Pharmacology, Faculty of Pharmacy, University of Belgrade

Vojvode Stepe 450, 11221 Belgrade, Serbia

E-mail: aleksn@pharmacy.bg.ac.rs

\section{Introduction}

Dyslipidemia, characterized by increased levels of low-density lipoprotein cholesterol (LDL-C) and triglycerides, and low levels of high-density lipoprotein cholesterol (HDL-C) are the major risk factors for the development of atherosclerosis and associated diseases as well (coronary artery, ischemic cerebrovascular and peripheral vascular disease). They are the major cause of morbidity and mortality among middle-aged adults as well as in the elderly (1).
Statins are the first line drugs used in the dyslipidemia treatment. They generally reduce the LDL-C level by $25-50 \%$ and have a range of pleiotrophic effects as well. Intestinal cholesterol absorption inhibitors (ezetimibe) and bile acid sequestrants (not registered in Serbia)reduce LDL-C level in combination with statins by $15-20 \%$ and $10-20 \%$, respectively. The nicotinic acid acts by HDL-C augmentation (not registered in Serbia), while fibrates and omega 3 fatty acids lower triglycerides blood level as well.

According to the European Society of Cardiology (ESC) and the European Atherosclerosis Society (EAS), the latest guidelines for dyslipidemia management shows that statins are the drugs of choice for the treatment of hyperlipoproteinemia. If the goal is not reached by the use of statins, the combination of statin and ezetimibe, or a bile acid sequestrant, as a second line, should be considered as an adjunct. In patients with statin intolerance, ezetimibe or bile acid sequestrants should be used. In a group of high-risk patients, with persistent high LDL-C despite the maximal tolerated statin dose, in combination with ezetimibe or in patients with statin intolerance, the use of a new group of lipid-lowering agents, like PCSK9 inhibitors, should be considered (2). 
It is important to emphasize that in spite of statin effectiveness in reducing the risk of $\mathrm{CV}$ events by $30 \%$, residual risk still remains, indicating that there is a need for additional drugs to reduce the residual risk further more.

New drugs for dyslipidemia treatment include proprotein convertase subtilisin/kexin type 9 (PCSK9) inhibitors, apolipoprotein B (apoB) synthesis inhibitors, microsomal triglyceride transfer protein (MTP) inhibitors and cholesteryl ester transfer protein (CETP) inhibitors, that are either already approved for the use in specific indications or are in the advanced stages of clinical investigation. The aim of our work was to make an overview of these new groups of drugs in the treatment of dyslipidemia with an overview of their mechanism of action, adverse effects and results of clinical trials, as well as their current place in the therapy.

\section{Methods}

With a view of collecting data about new lipidlowering agents, we used several sources of information. Most data were collected by searching a large database MEDLINE:

(http://www.ncbi.nlm.nih.gov/pubmed), using the key words "dyslipidemia", "hyperlipidemia" and "familial hypercholesterolaemia" in combination with "PCSK9 inhibitors" "alirocumab", "evolocumab", "mipomersen", "MTP inhibitors", "CETP inhibitors", "new drugs" and "clinical trials". In databases, from 2001-2016, we searched for: review articles relating to the new lipid-lowering agents and clinical studies which investigated the effectiveness and side effects of the new lipid-lowering agents (original articles), as well as the latest guidelines for the treatment of dyslipidemia. Each paper was reviewed and further analyzed. The references of the found articles were examined in order to identify additional studies. Priority was given to manuscripts published in the past 5 years, randomized placebo-controlled trials, and meta-analyses. Overall, 7 review papers and 19 clinical studies were used.

\section{PCSK9 inhibitors}

Two PCSK9 inhibitors, alirocumab and evolocumab, are approved for the use in combination with statins for the treatment of heterozygous familial hypercholesterolemia $(\mathrm{FH})$, as well as in patients with clinical atherosclerotic CV diseases who require additional LDL-C level reduction $(3,4)$. Evolocumab is also approved for the use in the patients with homozygous $\mathrm{FH}$ (4). It should be noted that these two drugs were registered in the Republic of Serbia, evolocumab in December 2016, and alirocumab in April 2017. The clinical development program for bococizumab was discontinued in November 2016 because of an unanticipated attenuation of LDL-C lowering over time, as well as a higher level of immunogenicity and higher rate of injection-site reactions than are shown with the other agents in this class (5). Few different PCSK9 inhibitors (e.g. monoclonal antibodies LGT-209, RG-7652) are currently in the phase I or II clinical studies (1).
In October 2016, ESC/EAS Task Force consensus statement for the use of PCSK9 inhibitor treatment in patients at very high risk of recurrent cardiovascular events with poorly controlled LDL-C levels was published. It is recommended that the treatment with a PCSK9 inhibitor may be considered in very high risk patients with clinical atherosclerotic $\mathrm{CV}$ diseases, including those with progressive form of CV disease or diabetes mellitus (with target organ damage or a major CV factor); or in patients with severe $\mathrm{FH}$ without atherosclerotic CV diseases with substantially elevated LDL-C levels despite maximal statin/ezetimibe therapy. In addition, patients with verified statin intolerance may be also considered for treatment with these agents (6).

PCSK9 is a serine protease that plays a central role in cholesterol metabolism in the liver by enhancing the degradation of $\operatorname{LDL}$ receptors $(7,8)$. Serum level of LDL-C is controlled predominately by the hepatic LDL receptors. When LDL-C binds to LDL receptor, the complex undergoes endocytosis, thus removing $L D L-C$ from the circulation. After releasing LDL-C, LDL receptor is then either degraded or recycled back to the cell surface (8). Circulating PCSK9 binds to the LDL receptors directing them to the lysosomes for degradation and preventing the receptor recycling process after internalization. By inhibiting this protein, PCSK9 inhibitors reduce LDL receptors degradation and increase expression of LDL receptors resulting in LDL-C level reduction (Figure 1) $(1,8)$.

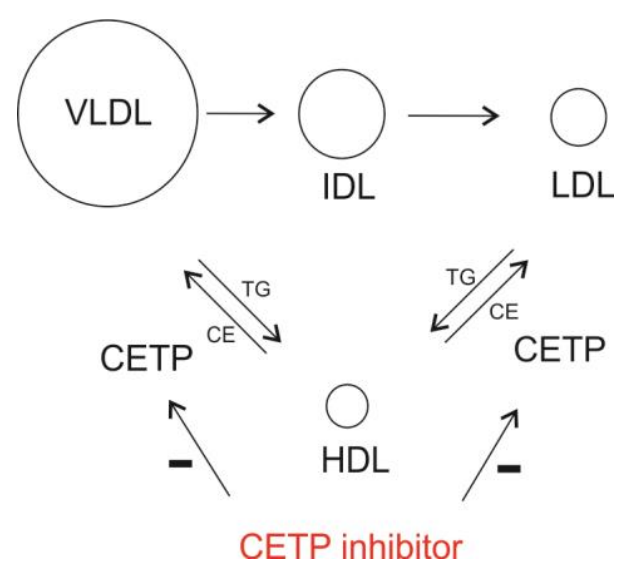

Figure 1. Mechanism of action of PCSK9 (proprotein convertase subtilisin/kexin type 9) inhibitors (adapted from reference 1 )

LDL - low-density lipoproteins; LDLR - LDL receptor

Results of clinical trials have shown that PCSK9 inhibitors reduce LDL-C level by $50-60 \%$ independent from the presence of a background therapy with statins or other lipid-lowering agents (2). They are well tolerated, while the most common adverse effects include injection site reaction (erythema, pain, bruises, itching, swelling), as well as nasopharyngitis, upper respiratory tract infections, influenza, back 
pain, arthralgia, myalgia, nausea. Hypersensitivity reactions (e.g., pruritus, rash, urticaria), including some serious events, like hypersensitivity vasculitis and hypersensitivity reactions requiring hospitalization, have been reported with alirocumab treatment. These allergic reactions, as well as elevated liver enzymes, were the most common causes of alirocumab treatment discontinuation. It should be noted that small but significant number of neurocognitive effects was described, but this finding requires further scrutiny. PCSK9 inhibitors are administered subcutaneously. The recommended doses for evolocumab are $140 \mathrm{mg}$ once every 2 weeks or $420 \mathrm{mg}$ monthly (both doses are equivalent), while alirocumab is administered from an initial $75 \mathrm{mg}$ to a maximum of $150 \mathrm{mg}$ every 2 week (or alternatively 300 mg monthly). After single-dose subcutaneous administration, the maximum serum concentrations of evolocumab are reached in 3-4 days, i.e. in 3-7 days after administration of alirocumab, while their bioavailability is $72 \%$ and $85 \%$, respectively. They are primarily distributed in circulation with limited distribution in tissues. Metabolism is not investigated as proteins (human monoclonal antibodies of the class IgG2 (evolocumab) and IgG1 (alirocumab)) are expected to degrade to small peptides and individual amino acids. The median apparent half-life of evolocumab at steady state was 11 to 17 days, i.e. 17 to 20 days of alirocumab. Concomitant administration of PCSK9 inhibitors with a statin leads to an increase in clearance and a decrease in the median apparent half-life of PCSK9 inhibitors, but without affecting their pharmacodynamic effect and the need for dosage adjustment. Also, no dosage adjustments are required depending on age, sex, race, body weight, nor in patients with mild and moderate liver and renal impairment (they were not studied in patients with severe impairment) $(9,10)$.

Until now, PCSK9 inhibitors have been investigated in healthy subjects, patients with statin intolerance, patients at high CV risk, as well as in patients with $\mathrm{FH}$ receiving maximally tolerated statin doses ( \pm other lipid-lowering agents) (11).

Evolocumab has been investigated within 5 phase II and 7 phase III trials. However, the problem is that all of them were short-term studies; therefore it was necessary to conduct long-term investigation of evolocumab. Hence, OSLER program, that included 4,465 patients, was designed with primary goal of obtaining the longer-term data on safety, side-effect profile and LDL-C reduction and also included an exploratory analysis on CV outcomes.

OSLER program consists of two clinical trials OSLER 1 and OSLER 2 that included patients who had already been involved in a variety of phase II and phase III trials that examined evolocumab.

One group of patients received the evolocumab (140 mg every 2 weeks or $420 \mathrm{mg}$ once a month) in combination with statins and other lipidlowering agents, while the other group received standard therapy (statin or other lipid-lowering agents). The LDL-C level, safety and the incidence of CV events (myocardial infarction, stroke, need for revascularization and CV death) were followed during the average period of 11.1 months (12).
The OSLER program results showed that evolocumab, when compared with standard therapy, reduced the LDL-C level by $61 \%$ ( $p<0.001)$, from the median baseline of $120 \mathrm{mg} / \mathrm{dL}$ to $48.3 \mathrm{mg} / \mathrm{dL}$ after 12 weeks. This reduction in LDL-C level was consistent over 48 weeks. Changes in other atherogenic lipid fractions were similar, non-HDL-C was reduced by $52.0 \%$, apoB by $47.3 \%$, total cholesterol by $36.1 \%$, triglycerides by $12.6 \%$ and lipoprotein(a) $(\mathrm{Lp}(\mathrm{a}))$ by $25.5 \%$ ( $p<0.001$ for all comparisons). Evolocumab raised levels of HDL cholesterol by $7.0 \%$ and apolipoprotein $\mathrm{A} 1$ (apo A1) by $4.2 \%$, as compared with standard therapy ( $p<0.001$ for both comparisons). There were no differences in the rates of overall adverse events, serious adverse events, elevations in AST and ALT ( $>3 x$ the upper limit of normal) or creatine kinase ( $>5 x$ the upper limit of normal) levels. However, injection-site reactions, neurocognitive adverse events, as well as some nonspecific adverse events, such as arthralgia, headache, fatigue, were reported more frequently in the evolocumab group (12).

The results of particular interest, which should be confirmed by additional studies, are those showing that patients in evolocumab group had significantly lower rate of all CV events $(0.95 \%)$ than did patients in the standard-therapy group $(2.18 \%)$ ( $p=$ 0.003 ) during one year (12). In May 2017, results from randomized, double-blind, placebo-controlled FOURIER (Further Cardiovascular Outcomes Research with PCSK9 Inhibition in Subjects with Elevated Risk) trial involving more than 27,500 patients with atherosclerotic cardiovascular disease who were receiving statin therapy, were published. The primary efficacy end point was the composite of myocardial infarction, stroke, hospitalization for unstable angina, coronary revascularization or cardiovascular death, and the median duration of follow-up was 2.2 years. Patients were randomly assigned to receive evolocumab or matching placebo as an addition to standard statin therapy. Results showed that reduction in LDL cholesterol levels with evolocumab was from a median baseline value of $2.4 \mathrm{mmol} / \mathrm{l}$ to $0.8 \mathrm{mmol} / \mathrm{l}$ and, relative to placebo, evolocumab treatment significantly reduced the risk $(15 \%)$ of the primary end point $(9.8 \%$ in evlocumab group vs. $11.3 \%$ in placebo group, $p<0.001)$. There was no significant difference between the study groups with regard to adverse events (including new-onset diabetes and neurocognitive events), with the exception of injectionsite reactions, which were more common with evolocumab (2.1\% vs. $1.6 \%$ ) (13). Secondary analysis of this study showed that patients who achieved progressively lower LDL-C concentrations in the FOURIER trial had progressively fewer cardiovascular events with no evidence of a plateau and with no increase in adverse events. Although most evaluated safety endpoints would be expected to manifest within the 2.2 years of follow-up, the adverse events such as cancer can take longer to manifest. Consequently, two long-term extension studies of FOURIER following approximately 6,600 patients (NCT03080935 and NCT02867813) that are planned to last 5 years should provide longer-term insights (14).

Alirocumab was investigated during 14 phase III trials within ODYSSEY program, which included 
more than 23,500 patients with uncontrolled hypercholesterolemia (those with $\mathrm{FH}$, those at high $\mathrm{CV}$ risk and those with statin intolerance) (11).

Most attention was attracted by ODYSSEY LONG TERM trial which was aimed to obtain longerterm data on safety and reduction in LDL-C levels by alirocumab, but the data on the incidence of $\mathrm{CV}$ events was also collected for a post hoc analysis. The study included 2,341 patients at high CV risk (patients with heterozygous $\mathrm{FH}$ with or without documented $\mathrm{CV}$ disease or patients with hypercholesterolemia and documented CV disease) who had LDL-C levels $\geq 70$ $\mathrm{mg} / \mathrm{dL}(1.8 \mathrm{mmol} / \mathrm{L})$ despite therapy with statins at maximally tolerated dose, with or without other lipidlowering drugs. Patients received alirocumab $150 \mathrm{mg}$ or placebo every 2 weeks for 78 weeks. After 24 weeks, there was a significant difference in the LDL$C$ levels reduction between alirocumab and placebo $(62 \%, p<0.001)$, with the mean absolute reduction of $74 \mathrm{mg} / \mathrm{dL}(1.9 \mathrm{mmol} / \mathrm{L})$ and $4 \mathrm{mg} / \mathrm{dL} \quad(0.1$ $\mathrm{mmol} / \mathrm{L})$, respectively. This effect remained consistent over a period of 78 weeks. The percentage of patients with any adverse events was similar in the two groups ( $81 \%$ with alirocumab and $82.5 \%$ with placebo). Specific adverse events that were reported with higher rates in the alirocumab group involve injection-site reaction, myalgia, neurocognitive events (amnesia, memory impairment, confusional state) and ophthalmologic events (15).

It should be noted that in a post hoc analysis there was a reduction in the rate of $\mathrm{CV}$ events ( $\mathrm{CV}$ death, nonfatal myocardial infarction, fatal or nonfatal ischemic stroke, unstable angina requiring hospitalization) in patients who received alirocumab $(1.7 \%)$ compared to patients who received placebo (3.3\%) $(p=0.02)(15)$. Given that the number of CV events was small, a follow-up period relatively short, and that post hoc analysis was applied, the obtained data must be confirmed additionally.

ODYSSEY OUTCOMES trial will assess whether alirocumab significantly reduces $\mathrm{CV}$ morbidity and mortality in more than 18,000 patients with recent acute coronary syndrome. Results of the study are expected in 2018 (11).

\section{ApoB synthesis inhibitor - mipomersen}

Mipomersen was approved in the United States of America (USA) for treating patients with homozygous $\mathrm{FH}$ as an addition to diet and maximally tolerated doses of statins and other lipid-lowering medications (16). However, in 2013, The Committee for Medicinal Products for Human Use (CHMP) of European Medicines Agency (EMA) recommended, for the second time, the refusal of the marketing authorisation for the mipomersen in European Union (EU). Reasons are as follows: a high proportion of patients stopped taking the medicine within two years (even in the group of patients with homozygous $\mathrm{FH}$ ) mainly due to side effects, then, long-term consequences of a built-up of fat in the liver and increased enzyme levels and potential irreversible liver damage, as well as more $\mathrm{CV}$ events reported in patients taking this medicine (17).

Mipomersen is a drug which can reduce LDL-C level by an additional $25 \%$ in homozygous $\mathrm{FH}$ pati- ents when given in combination with maximum tolerated doses of lipid-lowering agents. It is an "anti sense" oligonucleotide, 20 nucleotides in length, designed to block the production of apoB by attaching to the genetic material of cells responsible for producing it (Figure 2) (18).

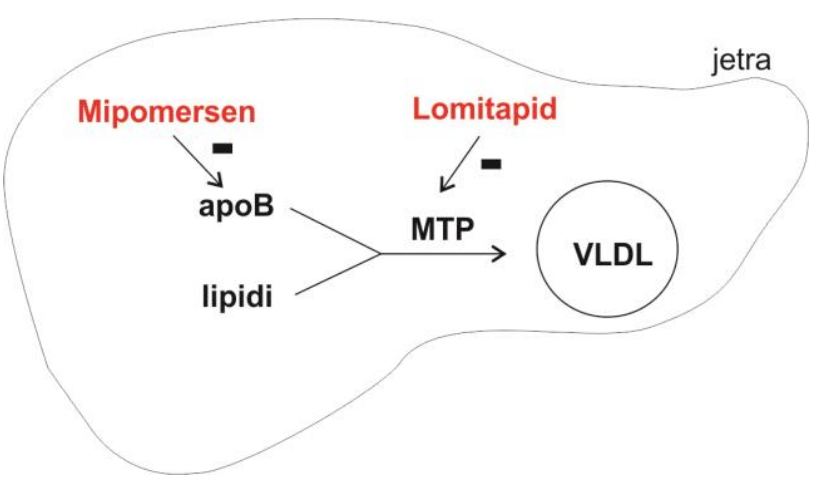

Figure 2. Mechanism of action of mipomersen and lomitapide apoB - apolipoprotein B;

MTP - microsomal triglyceride transfer protein; VLDL - very low-density lipoproteins.

ApoB is a crucial structural and functional component of all atherogenic lipoproteins. The human APOB gene encodes a single RNA transcript from which 2 isoforms, apoB-100 and apoB-48, are translated as a result of messenger RNA editing. ApoB-100, which is an essential structural component of very low-density lipoproteins (VLDL) and LDL-C, is produced predominantly by hepatocytes, while apoB-48, which is an essential structural component of chylomicrons, is produced predominantly by enterocytes. Mipomersen is complementary to the coding region of the messenger RNA for apo B-100. The hybridization of mipomersen to the target messen-ger RNA results in ribonuclease $\mathrm{H} 1$-mediated degradation of messenger RNK, leading to the reduction of apoB-100 production and hence, synthesis of VLDL and LDL-C is reduced $(18,19)$.

It should be noted that apoB has been identified as a new risk factor for atherosclerosis development. It is shown that apoB level is correlated to CV risk (19). The AMORIS study (Apolipoprotein-related MOrtality RISk study) indicated that elevated apoB is a more significant predictor of fatal myocardial infarction than LDL-C alone (20).

Mipomersen is administrated subcutaneously, usually in the dose of $200 \mathrm{mg}$ once weekly. Following subcutaneous injection, maximal plasma concentrations are reached in 3 to 4 hours, while bioavailability of mipomersen ranged from $54 \%$ to $78 \%$. Mipomersen is highly bound to human plasma proteins ( $\geq$ $90 \%$ ) and, with once weekly dosing, plasma levels approach steady state typically within 6 months. Elimination half-life for mipomersen is approximately 1 to 2 months. This drug is not a substrate for the CYP450 metabolism, so, there are no clinically rele- 
vant pharmacokinetic interactions between mipomersen and warfarin or between mipomersen and simvastatin or ezetimibe (18).

In clinical trials, mipomersen has been studied in healthy volunteers (21), in patients on statin therapy $(22,23)$ and in patients with $\mathrm{FH}(24-26)$.

In a study which involved 36 healthy volunteers with mild hypercholesterolemia, administration of mipomersen in doses ranging from 50 to $200 \mathrm{mg}$ for 4 weeks, showed a dose-dependent and prolonged reduction in $\mathrm{apoB}$ and $\mathrm{LDL}-\mathrm{C}$ with the maximum reduction from baseline of $50 \%$ and $35 \%$, respectively, in the 200-mg dose group (21). In addition, a study (Dose-Escalating Safety Study in Subjects on Stable Statin Therapy) which involved 74 patients on stable statin therapy, showed that application of mipomersen during 5 weeks reduced LDL-C levels ranged from $18 \%$ to $49 \%$ relative to the placebo-control group at doses of $100 \mathrm{mg}$ and higher. Within this study, the reduction in apoB and LDL-C of $36 \%$ from baseline was demonstrated in a group of 12 patients treated with $200 \mathrm{mg}$ mipomersen over 13 weeks, what is more significant than the effect observed in the same-dose 5-week treatment group (22).

The efficacy of mipomersen therapy in patients with $\mathrm{FH}$ was confirmed in several phase II and III trials on the basis of which it is approved for this indication by the US Food and Drug Administration (FDA). For example, mipomersen was studied in phase III trial which involved 51 patients with homozygous $\mathrm{FH}$ already receiving maximum tolerated dose of lipid-lowering medications. The primary endpoint was percentage change in LDL-C concentration from baseline. After 26 weeks, patients receiving $200 \mathrm{mg}$ of mipomersen subcutaneously once weekly had more significant LDL-C reduction (-24.7\%) compared with placebo $(-3.3 \%, p=0.0003)$. The most common adverse events were injection site reactions (76\% mipomersen vs. $24 \%$ placebo), and 4 patients (12\%) receiving mipomersen had elevation in $A L T \geq 3 x$ the upper limit of normal (21).

The adverse reactions of mipomersen for pooled Phase III clinical trials are: injection site reactions $(84 \%)$, flu-like symptoms ( 30\%, which typically occur within 2 days after an injection), elevations in serum transaminases (specifically ALT, $\sim 10 \%$ ), hepatic steatosis (with or without concomitants increases in transaminases), gastrointestinal (30\%), neurological (25\%) and psychiatric (10\%) disorders. Due to the risk of hepatotoxicity, mipomersen is available only trough a limited REMS (Risk Evaluation and Mitigation Strategy) program in which it could be prescribed and distributed only by certified physicians and pharmacists aiming to monitor patients because of the risk of side effects (18).

\section{MTP inhibitor - Iomitapide}

Lomitapide was approved in 2012 by FDA, in 2013 by EMA, followed by marketing authorisation in Canada, Mexico, Taiwan and Japan for treating patients with homozygous $\mathrm{FH}$ as an addition to diet and maximum tolerated doses of statins and other lipidlowering medications (11, 27-29). In homozygous $\mathrm{FH}$ patients, lomitapide can additionally reduce LDL$\mathrm{C}$ levels by up to by $50 \%$.
Lomitapide is an orally active, small molecule that directly binds to MTP, a protein localized in an endoplasmic reticulum, the role of which is to transport triglycerides, phospholipids and cholesterol esters to the newly synthesized apoB. This is a key step in the synthesis of VLDL in hepatocytes and chylimicrons in enterocytes (Figure 2) $(30,31)$. Inhibition of this protein in hepatocytes leads to a decrease in the VLDL concentration in the circulation and, consequently, to a decrease in LDL-C (32). In addition, inhibition of MTP in enterocytes can reduce plasma triglyceride levels by reducing fat absorption from foods through chylomicron (1).

After oral administration, the bioavailability of lomitapide is $7 \%$, which is largely due to the extensive first pass effect. Maximum plasma concentrations were reached after 4-8 hours, and despite a high binding rate for plasma proteins ( $>99.8 \%$ ), it has a high volume of distribution. Lomitapide has an extensive liver metabolism, predominantly via CYP450 3A4, while other isoforms (2E1, 1A2, 2B6, 2C8 and 2C19) are involved to a lesser extent. The elimination halflife of lomitapide was approximately 29 hours. Because lomitapide is metabolized by CYP3A4, concomitant use with strong or moderate CYP3A4 inhibitors (e.g., antifungal azoles such as itraconazole, fluconazole, ketoconazole, voriconazole, posaconazole; macrolide antibiotics such as erythromycin or clarithromycin; ketolide antibiotics such as telithromycin; HIV protease inhibitors; the calcium channel blockers diltiazem and verapamil, and the anti-arrhythmic dronedarone) is contraindicated.

If treatment with these drugs is unavoidable, lomitapide should be stopped during the course of treatment. When administered with atorvastatin, a weak CYP3A4 inhibitor, the dose of lomitapide should either be taken 12 hours apart or be decreased by half. Lomitapide increases plasma concentrations of statins, which increases the risk of myopathy, requiring additional caution and monitoring. Concomitant administration of $>40 \mathrm{mg}$ simvastatin is contraindicated. There is no need for dose adjustment in concomitant administration with fenofibrate, niacin or ezetimibe. Also, lomitapide increases the plasma concentration of warfarin, so regular monitoring of the INR (international normalized ratio) is recommended. Simultaneous use of St. John's Wort, grapefruit and alcohol with this drug should be avoided, and it may affect the absorption of fat-soluble nutrients (e.g. vitamin E) (33).

Lomitapide was studied in several phase II and III trials. For example, in the phase III HoFH Lomitapide Study, efficacy and safety of lomitapide was investigated in 29 patients with homozygous $\mathrm{FH}$ receiving appropriate lipid-lowering therapy. The primary endpoint was mean percent change in levels of LDL-C from baseline to week 26, after which patients remained on lomitapide through to week 78 for safety assessment. Lomitapide, at median dose of $40 \mathrm{mg}$ (a starting dose was $5 \mathrm{mg}$ and then escalated to the maximum of $60 \mathrm{mg}$ ), reduced LDL-C by $50 \%$, from $8.7 \mathrm{mmol} / \mathrm{L}$ at baseline to $4.3 \mathrm{mmol} / \mathrm{L}$ after 26 weeks ( $p<0.0001)$. Concentrations of LDL-C remained reduced by $44 \%(p<0.0001)$ at week 56 and $38 \%$ $(p<0.0001)$ at week 78. Changes in levels of total cholesterol, apoB and triglycerides were similar with 
change in LDL-C. During this study, side effects of lomitapide were mainly related to the gastrointestinal system. Four patients had AST/ALT $>5 x$ the upper limit of normal, which resolved after dose reduction or temporary interruption of lomitapide, but there were no permanent discontinuation of treatment because of liver abnormalities (34).

The most serious adverse reactions during treatment with lomitapide were just liver aminotransferase abnormalities. Hepatic steatosis (with or without concomitants increases in transaminases) is also reported, and because of the risk of hepatotoxicity, like mipomersen, it is available trough the REMS program (33).

The most common adverse events of lomitapide, reported by $93 \%$ of patients, were gastrointestinal. Among them, diarrhoea occurred in $79 \%$ of patients, nausea in $65 \%$, dyspepsia in $38 \%$, vomiting in 34\%, while flatulence, constipation and abdominal pain were reported by at least $20 \%$ of patients. These side effects are the result of its mechanism of action, and may affect the absorption of the concomitantly administered oral drugs (33).

Due to the fetal toxicity, based on findings of teratogenicity animals, females of reproductive potential should have a negative pregnancy test before starting lomitapide and use contraception during treatment (33).

\section{Bempedoic acid}

Bempedoic acid is a novel, oral LDL-C lowering drug that significantly reduces elevated LDL-C levels in patients with hypercholesterolemia, including patients inadequately treated with current lipid-modifying therapies. It works in the liver to block cholesterol biosynthesis by direct ATP citrate lyase (ACL) inhibition, a key enzyme that supplies substrate for cholesterol and fatty acid synthesis in the liver, resulting in up-regulation of LDL receptor (35).

To date, bempedoic acid has been studied in eighteen completed Phase 1 and Phase 2 clinical studies which showed clinically relevant LDL-C lowering results of up to $30 \%$ as monotherapy, approximately $50 \%$ in combination with ezetimibe, and an incremental $20 \%$ + when added to stable statin therapy (any statin at any dose). Currently, bempedoic acid is evaluated in four global Phase 3 LDL-C lowering efficacy and safety studies on approximately 3,200 patients at high CV risk with hypercholesterolemia on optimized background lipid-modifying therapy, and one cardiovascular outcomes trial (Cholesterol Lowering via BEmpedoic Acid, an ACL-inhibiting Regimen (CLEAR) Outcomes) which is expected to enrol approximately 12,600 patients in approximately 30 countries $(35,36)$. In addition, initiation of a single global Phase 3 bridging study (1002FDC-053), to evaluate the efficacy and safety of the bempedoic acid / ezetimibe combination, is planned and it is expected to enroll up to 350 patients (37). Results of Phase III program are expected during 2018 (36, 37).

\section{CETP inhibitors}

In recent years, extensive research is being carried out to identify new HDL-raising drugs hoping that this would lead to further reduction of cardiovascular risk. Currently, CETP inhibitors are being actively studied for that purpose (38).

The role of CETP is to promote the transfer of cholesteryl esters between plasma lipoproteins, therefore, CETP inhibition raises HDL-C levels and decreases LDL-C levels (Figure 3) (39). Epidemiological data have clearly demonstrated a strong inverse relationship between HDL-C levels and the risk of $\mathrm{CV}$ events (40-42).

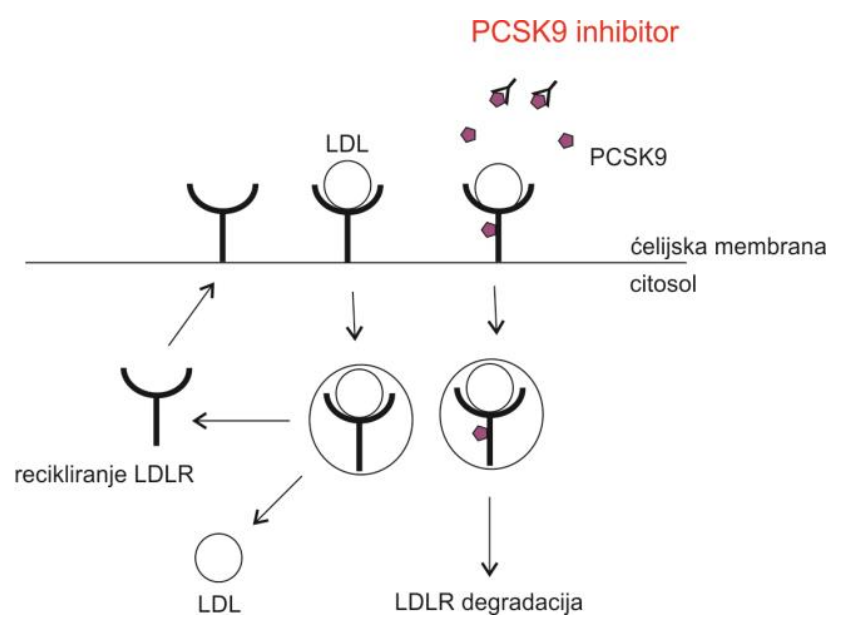

Figure 3. Mechanism of action of CETP (cholesteryl ester transfer protein) inhibitors VLDL - very low-density lipoproteins;

IDL - intermediate density lipoprotein; LDL - low-density lipoproteins; $\mathrm{HDL}$ - high-density lipoproteins; CE - cholesteryl esters; TG - triglyceride.

Torcetrapib, dalcetrapib, evacetrapib and anacetrapib are CETP inhibitors reaching phase III clinical trials. However, the torcetrapib trial was terminated prematurely because of mortality increase (CV and overall). Since the increase in mortality and increase in blood pressure $(5.4 \mathrm{mmHg})$ was probably not caused by mechanism of action of torcetrapib, but, at least in part, by increased level of aldosterone as well as plasma electrolyte composition changes lower potassium levels and increased sodium and bicarbonate levels (43), the testing of new CETP inhibitors is continued. Trials with dalcetrapib and evacetrapib were terminated due to insufficient efficacy. Although these drugs significantly raised HDL-C level, they failed to show a significant reduction in cardiovascular events $(44,45)$. Effects of anacetrapib on cardiovascular outcomes are currently being evaluated in the ongoing REVEAL (Randomized Evaluation of the Effects of Anacetrapib through Lipid Modification) trial, a phase III trial on over 30,000 patients with atherosclerotic vascular disease who were receiving intensive atorvastatin therapy. Although the study completion is planned for 2019, the first results, after the median follow-up period of 4.1 years, showed that the addition of anacetrapib to intensive statin therapy resulted in a lower incidence 
of major coronary events (coronary death, myocardial infarction, coronary revascularization) than the addition of placebo, despite very well-controlled baseline LDL cholesterol levels. The proportional risk reductions appeared to be larger with more prolonged follow-up. Anacetrapib did not affect the mortality rate (from cardiovascular or non-cardiovascular causes), the incidence of cancer, or any significant excesses in any major category of the adverse events. Patients who received anacetrapib had slightly higher blood pressure levels $(0.7 \mathrm{mmHg}$ systolic and 0.3 $\mathrm{mmHg}$ diastolic) compared to the placebo group, but there was no difference in the rate of adverse effects associated with hypertension. Also, there were slightly higher rates of moderate elevations in creatine kinase in the anacetrapib group than in the placebo group, but slightly lower rates of more severe elevations (> 40 times the upper limit of the normal range) (46). Results of this trial are expected to provide a final answer to the question whether CETP inhibitors might actually be effective for the reduction of cardiovascular risk or further investigation of this group of drugs should be discontinued.

\section{Conclusion}

Results of numerous clinical studies conducted during the past three decades clearly show that statin therapy significantly reduces the level of LDL-C as well as the occurrence of CV events and mortality. However, a significant number of patients using statins do not achieve the desired levels of LDL-C, especially those with high or very high CV risk. In addition, patients intolerant of statins should also be mentioned, as well as those with contraindications to these drugs. For these reasons, there is a need for some new lipid-lowering agents in therapy, which will further reduce not only the level of LDL-C, but also the occurrence of CV events.

Currently, the most promising agents are PCSK9 inhibitors. It has been shown that they produce significant LDL-C level reduction, and that they are well tolerated by patients. They are approved for use in combination with statins for the treatment of heterozygous $\mathrm{FH}$, and in patients with clinical atherosclerotic CV diseases. In addition, evolocumab is approved for use in patients with homozygous $\mathrm{FH}$.

Mipomersen, apoB synthesis inhibitor, and lomitapide, an oral MTP inhibitor, are currently approved, for treating patients with homozygous $\mathrm{FH}$ as an addition to statins and other lipid-lowering medications. Their usage is significantly limited by the high risk of hepatotoxicity.

Although the new lipid-lowering agents produce significant LDL-C level reduction, it is necessary to conduct longer trials with more patients, confirming their efficacy and safety, thus enabling their wider use for the treatment of dyslipidemia.

\section{Conflict of interest}

Authors declare no conflict of interest. 


\section{References}

1. Ahn $\mathrm{CH}$, Choi $\mathrm{SH}$. New drugs for treating dyslipidemia: beyond statins. Diabetes Metab J 2015;39:87-94. [CrossRef][PubMed]

2. Catapano AL, Graham I, De Backer G, et al. 2016 ESC/EAS Guidelines for the Management of Dyslipidaemias: The Task Force for the Management of Dyslipidaemias of the European Society of Cardiology (ESC) and European Atherosclerosis Society (EAS) Developed with the special contribution of the European Assocciation for Cardiovascular Prevention \& Rehabilitation (EACPR). Atherosclerosis 2016;253:281-344. [CrossRef][PubMed]

3. U.S. Food and Drug Administration (2015). FDA approves Praluent to treat certain patients with high cholesterol. [press announcements] July 24, 2015. Available from:

(http://www.fda.gov/NewsEvents/Newsroom/PressAnn ouncements/ucm455883.htm)

4. U.S. Food and Drug Administration (2015). FDA approves Repatha to treat certain patients with high cholesterol. [press announcements] August 27, 2015. Available from:

http://www.fda.gov/NewsEvents/Newsroom/PressAnn ouncements/ucm460082.htm

5. Pfizer Inc. (2016). Pfizer Discontinues Global Development of Bococizumab, Its Investigational PCSK9 Inhibitor. [press release] November 1, 2016. Available from:

http://www.pfizer.com/news/press-release/ press relea se-detail/pfizer discontinues global development deve lopment of bococizumab its investigational pcsk9 inhitor

6. Landmesser $U$, John Chapman $M$, Farnier $M$, et al; European Society of Cardiology (ESC) and the European Atherosclerosis Society (EAS). European Society of Cardiology/European Atherosclerosis Society Task Force consensus statement on proprotein convertase subtilisin/kexin type 9 inhibitors: practical guidance for use in patients at very high cardiovascular risk. Eur Heart J. 2016. pii: ehw480. [CrossRef]

7. Abifadel $M$, Varret $M$, Rabès JP, et al. Mutations in PCSK9 cause autosomal dominant hypercholesterolemia. Nat Genet 2003;34:154-6. [CrossRef][PubMed]

8. Do RQ, Vogel RA, Schwartz GG. PCSK9 Inhibitors: potential in cardiovascular therapeutics. Curr Cardiol Rep 2013;15:345. [CrossRef][PubMed]

9. REPATHA [sažetak karakteristika leka]. Beograd; PHARMASWISS D.O.O., BEOGRAD; 2016.

10. PRALUENT [prescribing information]. Bridgewater, NJ 08807; sanofi-aventis U.S. LLC; 2017.

11. Agabiti Rosei E, Salvetti M. Management of Hypercholesterolemia, Appropriateness of Therapeutic Approaches and New Drugs in Patients with High Cardiovascular Risk. High Blood Press Cardiovasc Prev 2016; 23:217-30. [CrossRef][PubMed]

12. Sabatine MS, Giugliano RP, Wiviott SD, et al. OpenLabel Study of Long-Term Evaluation against LDL Cholesterol (OSLER) Investigators. Efficacy and safety of evolocumab in reducing lipids and cardiovascular events. N Engl J Med 2015;372:1500-9. [CrossRef][PubMed]

13. Sabatine MS, Giugliano RP, Keech AC, et al. FOURIER Steering Committee and Investigators. Evolocumab and Clinical Outcomes in Patients with Cardiovascular Disease. N Engl J Med 2017;376:1713-22. [CrossRef][PubMed]
14. Giugliano RP, Pedersen TR, Park JG, et al. FOURIER Investigators. Clinical efficacy and safety of achieving very low LDL-cholesterol concentrations with the PCSK9 inhibitor evolocumab: a prespecified secondary analysis of the FOURIER trial. Lancet 2017; 390:1962-71 [CrossRef][PubMed]

15. Robinson JG, Farnier $M$, Krempf $M$, et al. ODYSSEY LONG TERM Investigators. Efficacy and safety of alirocumab in reducing lipids and cardiovascular events. $\mathrm{N}$ Engl J Med 2015;372:1489-99. [CrossRef][PubMed]

16. U.S. Food and Drug Administration (2013). FDA approves new orphan drug Kynamro to treat inherited cholesterol disorder. [press announcements] January 29, 2013. Available from: https://wayback.archiveit.org/7993/20170112023906/http://www.fda.gov/Ne wsEvents/Newsroom/PressAnnouncements/ucm33719 5.htm

17. European Medicines Agency. Committee for Medicinal Products for Human Use. Refusal of the matketing authorisation for Kynamro (mipomersen). Outcome of re-examination. March 21, 2013. EMA/177547/2013

18. KYNAMRO [prescribing information]. Chicago, IL; Kastle Therapeutics; 2016.

19. Ricotta DN, Frishman W. Mipomersen: A safe aneffective antisense therapy adjunct to statins in patients with hypercholesterolemia. Cardiol Rev 2012;20:90-5. [CrossRef]

20. Walldius $G$, Jungner I, Holme I, Aastveit AH, Kolar W, Steiner E. High apolipoprotein B, low apolipoprotein A$\mathrm{I}$, and improvement in the prediction of fatal myocardial infarction (AMORIS study): a prospective study. Lancet 2001; 358:2026-33. [CrossRef][PubMed]

21. Kastelein JJ, Wedel MK, Baker BF, Su J, Bradley JD, Yu $R Z$, et al. Potent reduction of apolipoprotein $B$ and lowdensity lipoprotein cholesterol by short-term administration of an antisense inhibitor of apolipoprotein B. Circulation 2006;114:1729-35. [CrossRef][PubMed]

22. Akdim F, Stroes ES, Sijbrands EJ, Tribble DL, Trip MD, Jukema JW, et al. Efficacy and safety of mipomersen, an antisense inhibitor of apolipoprotein B, in hypercholesterolemic subjects receiving stable statin therapy. J Am Coll Cardiol 2010;55:1611-8. [CrossRef][PubMed]

23. McGowan MP, Tardif JC, Ceska R, Burgess $D$, Soran $H$, Gouni-Berthold I, et al. Randomized, placebo-controlled trial of mipomersen in patients with severel hypercholesterolemia receiving maximally tolerated lipid-lowering therapy. PLoS One 2012;7(11):e49006. [CrossRef][PubMed]

24. Raal FJ, Santos RD, Blom DJ, Marais AD, Charng MJ, Cromwell WC, et al. Mipomersen, an apolipoprotein B synthesis inhibitor, for lowering of LDL cholesterol concentrations in patients with homozygous familial hypercholesterolaemia: a randomised, double-blind, placebo-controlled trial. Lancet 2010;375:998-1006. [CrossRef][PubMed]

25. Akdim F, Visser ME, Tribble DL, Baker BF, Stroes ES, Yu R, et al. Effect of mipomersen, an apolipoprotein B synthesis inhibitor, on low-density lipoprotein cholesterol in patients with familial hypercholesterolemia. Am J Cardiol 2010;105:1413-9. [CrossRef][PubMed]

26. Stein EA, Dufour R, Gagne C, Gaudet D, East C, Donovan JM, et al. Apolipoprotein B synthesis inhibition with mipomersen in heterozygous familial hypercholesterolemia: results of a randomized, double-blind, placebo-controlled trial to assess efficacy and safety as 
add-on therapy in patients with coronary artery disease. Circulation 2012;126:2283-92. [CrossRef][PubMed]

27. U.S. Food and Drug Administration (2012). FDA approves new orphan drug for rare cholesterol disorder. [press announcements] December 26, 2012. Available from:

http://www.fda.gov/NewsEvents/Newsroom/PressAnn ouncements/ucm333285.htm

28. European Medicines Agency. Committee for Medicinal Products for Human Use. Assessment report. Lojuxta. International non-proprietary name: Lomitapide. 30 May 2013. EMA/CHMP/274464/2013

29. Novelion Therapeutics (2016). Aegerion Pharmaceuticals' JUXTAPID ${ }^{\circ}$ Receives Pricing Authorization in Japan. [press release] CAMBRIDGE, Mass., November 17, 2016. Available from: http://www.novelion.com/about-novelion/news/112016/aegerion-pharmaceuticals-juxtapid\%C2\%AEreceives-pricing-authorization-japan

30. Choi SH, Ginsberg HN. Increased very low density lipoprotein (VLDL) secretion, hepatic steatosis, and insulin resistance. Trends Endocrinol Metab 2011;22:353-63. [CrossRef][PubMed]

31. Wetterau JR, Aggerbeck LP, Bouma ME, Eisenberg $C$, Munck $A$, Hermier $M$, et al. Absence of microsomal triglyceride transfer protein in individuals with abetalipoproteinemia. Science 1992;258:999-1001. [CrossRef][PubMed]

32. Cuchel M, Bloedon LT, Szapary PO, Kolansky DM, Wolfe $M L$, Sarkis A, et al. Inhibition of microsomal triglyceride transfer protein in familial hypercholesterolemia. $\mathrm{N}$ Engl J Med 2007;356:148-56. [CrossRef][PubMed]

33. LOJUXTA [summary of product caracteristics]. Uxbridge UB11 1BD, United Kingdm; Aegerion Pharmaceuticals; 2013.

34. Cuchel M, Meagher EA, du Toit Theron H, Blom DJ, Marais AD, Hegele RA, et al. Phase $3 \mathrm{HoFH}$ Lomitapide Study investigators. Efficacy and safety of a microsomal triglyceride transfer protein inhibitor in patients with homozygous familial hypercholesterolaemia: a singlearm, open-label, phase 3 study. Lancet 2013;381:40-6. [CrossRef][PubMed]

35. Esperion. Bempedoic Acid. Available from: http://www.esperion.com/development/bempedoicacid/
36. Esperion (2017). Esperion Announces FDA Confirmation Regarding Regulatory Pathway to Approval for an LDL-C Lowering Indication for Bempedoic Acid. [press release] ANN ARBOR, Mich., March 20, 2017. Available from: http://investor.esperion.com/releasedetail.cfm?releasei $\mathrm{d}=1017975$

37. Esperion (2017). Esperion Announces FDA Confirma-tion of Regulatory Pathway to Approval for the Com-bination of Bempedoic Acid and Ezetimibe. [press rele-ase] ANN ARBOR, Mich., Jun 26, 2017. Available from: http://investor.esperion.com/releasedetail.cfm?Release $\underline{\mathrm{ID}=1031363}$

38. Kosmas CE, DeJesus E, Rosario D, Vittorio TJ. CETP Inhibition: Past Failures and Future Hopes. Clin Med Insights Cardiol 2016;10:37-42. [CrossRef][PubMed]

39. Tall AR. Plasma cholesteryl ester transfer protein. J Lipid Res 1993;34:1255-74. [PubMed]

40. Castelli WP. Cholesterol and lipids in the risk of coronary artery disease-the Framingham Heart Study. Can J Cardiol 1988;4(suppl A):5A-10A. [PubMed]

41. Barter P, Gotto AM, LaRosa JC, et al; Treating to New Targets Investigators. HDL cholesterol, very low levels of LDL cholesterol, and cardiovascular events. N Engl J Med 2007;357:1301-10. [CrossRef][PubMed]

42. Kosmas CE, Christodoulidis G, Cheng JW, Vittorio TJ, Lerakis S. High-density lipoprotein functionality in coronary artery disease. Am J Med Sci 2014;347:504-8. [CrossRef][PubMed]

43. Barter PJ, Caulfield $M$, Eriksson $M$, et al. ILLUMINATE Investigators.Effects of torcetrapib in patients at high risk for coronary events. N Engl J Med 2007; 357: 2109-22. [CrossRef][PubMed]

44. Schwartz GG, Olsson AG, Abt M, et al. dal-OUTCOMES Investigators. Effects of dalcetrapib in patients with a recent acute coronary syndrome. N Engl J Med 2012; 367:2089-99. [CrossRef][PubMed]

45. Eli Lilly and Company (2015). Lilly to discontinue development of evacetrapib for high-risk atherosclerotic cardiovascular disease. [press release] Indianapolis, October 12, 2015. Available from: http://lilly.mediaroom.com/index.php?s=9042\&item $=1$ $\underline{37476}$

46. HPS3/TIMI55-REVEAL Collaborative Group, Bowman L, Hopewell JC, Chen F, et al. Effects of Anacetrapib in Patients with Atherosclerotic Vascular Disease. N Engl J Med 2017;377:1217-27. [CrossRef][PubMed] 


\title{
Revijalni rad
}

UDC: $615.272: 616-008.83$

doi: 10.5633/amm.2018.0109

\section{NOVI LEKOVI U TERAPIJI DISLIPIDEMIJA}

\author{
Aleksandra Novaković1, Marija Marinko ${ }^{1}$, Ivan Stojanovićz,3, \\ Dragoslav Nenezić ${ }^{2,3}$, Predrag Milojevićc,3, Vladimir Kanjuh ${ }^{4}$
}

\author{
${ }^{1}$ Univerzitet u Beogradu, Farmaceutski fakultet, Katedra za farmakologiju, Beograd, Srbija \\ 'Univerzitet u Beogradu, Medicinski fakultet, Beograd, Srbija \\ 3Institut za kardiovaskularne bolesti "Dedinje", Beograd, Srbija \\ ${ }^{4}$ Srpska akademija nauka i umetnosti, Beograd, Srbija
}

Kontakt: Aleksandra Novaković

Univerzitet u Beogradu, Farmaceutski fakultet, Katedra za farmakologiju

Vojvode Stepe 450, 11221 Beograd

E-mail: aleksn@pharmacy.bg.ac.rs

Dislipidemije su vodeći faktor rizika za razvoj ateroskleroze i njenih posledica, kao što su koronarna bolest srca, ishemična cerebrovaskularna i periferna vaskularna bolest. Ove bolesti su glavni uzrok mortaliteta, kako u svetu tako i u Evropi, gde su odgovorne za $45 \%$ ukupne smrtnosti. Terapija dislipidemija uključuje primenu: statina, ezetimiba, fibrata, niacina, smola koje vezuju žučne kiseline i omega-3 masnih kiselina. Od pomenutih lekova, vodeću ulogu u terapiji dislipidemija imaju statini. Treba istaći da uprkos primeni statina, koji redukuju rizik od pojave kardiovaskularnih (KV) događaja za oko $30 \%$, još uvek ostaje tzv. rezidualni rizik za nastanak KV događaja, što ukazuje da su potrebni novi lekovi koji će dalje redukovati rezidualni rizik. Novi lekovi u terapiji dislipidemija uključuju PCSK9 inhibitore, inhibitore sinteze apolipoproteina B (apoB), MTP inhibitore i CETP inhibitore, koji su ili već odobreni za primenu u određenim indikacijama, ili se nalaze u odmaklim fazama kliničkog ispitivanja. Alirokumab i evolokumab, dva PCSK9 inhibitora, odobrena su za primenu, u kombinaciji sa statinima, u terapiji heterozigotne familijarne hiperholesterolemije (FH), kao i kod bolesnika sa kliničkim aterosklerotičnim KV bolestima koji zahtevaju dodatnu redukciju nivoa lipoproteina male gustine (low-density lipoprotein cholesterol, LDL-C). Pored toga, evolokumab je odobren za primenu kod bolesnika sa homozigotnom FH. Mipomersen, inhibitor sinteze apoB, i lomitapid, oralni MTP inhibitor, su, odobreni za primenu samo kod bolesnika sa homozigotnom FH kao dodatak maksimalnoj tolerišućoj dozi statina i drugih hipolipemika. Iako novi hipolipemici značajno redukuju nivo LDL-C, neophodno je sprovesti studije, duže i sa većim brojem ispitanika, koje će potvrditi njihovu efikasnost i bezbednost i time omogućiti njihovu širu primenu u terapiji dislipidemija.

Acta Medica Medianae 2018;57(1):54-63.

Ključne reči: dislipidemije, PCSK9 inhibitori, mipomersen, lomitapid, CETP inhibitori 